
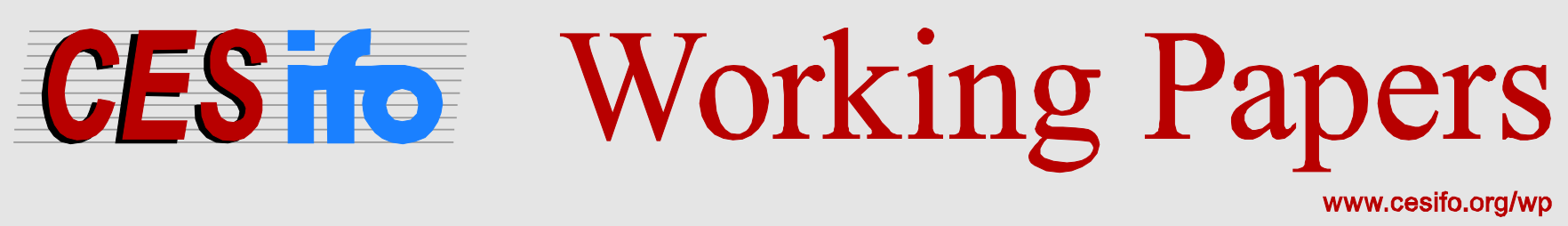

\title{
Taxation of Pensions in Portugal: Is there a Rationale for a Semi-Dual Income Tax System?
}

\author{
Jorge Miguel Bravo
}

\section{CESIFO WORKING PAPER NO. 5981 \\ CATEGORY 1: PUBLIC FinANCE \\ JUNE 2016}
An electronic version of the paper may be downloaded
- from the SSRN website: Www.SSRN.com
- from the RePEc website: Www.RePEc.org
- from the CESifo website: www.CESifo-group.org/wp




\title{
Taxation of Pensions in Portugal: Is there a Rationale for a Semi-Dual Income Tax System?
}

\begin{abstract}
The semi-dual income tax typically combines a progressive tax schedule for labour and pension income with low and often flat and differentiated nominal tax rates on some forms of capital income. This paper discusses the rationale for the adoption of semi-dual income tax in the taxation of public, occupational and private pensions and other retirement income, taking the Portuguese experience as a possible guide to other countries. The particular effects of pension taxation on the timing, level and composition of saving are assessed, together with horizontal and vertical equity, neutrality and risk-sharing concerns. Moving to a semi-dual income tax offers both advantages and disadvantages in addressing the pension system long term goals and challenges, and represents a compromise between domestic and international competing considerations an open economy faces in designing a tax regime. The adoption may be a result of a clear tax reform strategy or simply an outcome of particular economic, demographic, political and social circumstances. Providing separate tax rates for labour and capital income allows countries greater flexibility in addressing international tax competition and greater opportunity to retain and augment progressive tax rates for labour and pension income but tax induced distortions and arbitrage opportunities for income-shifting between categories should not be neglected given their impact on the taxable base for social contributions.
\end{abstract}

JEL-Codes: H200, H210, H240, H550.

Keywords: taxation of pensions, income tax reform, semi-dual income tax, capital income tax.

\author{
Jorge Miguel Bravo \\ Universidade Nova de Lisboa \\ Information Management School (NOVA IMS) \\ Lisbon / Portugal \\ jbravo@novaims.unl.pt
}

A first version of the paper was presented at the CEPAR \& CESifo Workshop on Pension Taxation, Population Ageing, and Globalisation (Part 2, Munich). I would like to thank the participants and Robert Holzmann for critical and helpful comments; any remaining errors and shortcomings are mine. 


\section{Introduction}

The Portuguese personal tax reform in 1989 established a comprehensive, progressive and unitary personal income tax system ${ }^{2}$. Since then, the system has evolved gradually towards a semi-dual income tax system with certain categories of income exempt from taxation and/or subject to flat nominal withholding tax rates as a result of a number of tax reforms. The semidual income tax combines a highly progressive tax schedule for labour and pension income with low and flat nominal tax rates on some forms of capital (personal and corporate) income. The departure from a comprehensive, progressive and symmetric income tax system is justified by a number of arguments such as international tax competition, capital mobility, economic efficiency, the special role of savings, equity and neutrality and risk-sharing considerations. Other important considerations such as pension system adequacy and sustainability, the need to increase saving for retirement, increasing fiscal constraints, high unemployment levels, the need to attract foreign direct investment, the challenges of European integration and globalization, off-shoring and disintermediation, or simply difficulties in assessing taxpayers real income influence the adoption of a particular taxation regime.

Despite numerous parametric reforms undertaken in the last decades, the latest as part of the 2011-2014 "Troika» bailout program, the Portuguese pension system continues to be dominated by a public PAYG earnings-related defined benefit scheme, comprising two separate but convergent plans, with voluntary occupational and personal funded schemes still playing a minor role in funding retirement income. The country was hit particularly hard by the economic and financial crisis and was compelled to cut pensions in payment and to reduce available incomes for older people through tax increases and temporary changes to the indexation of benefits. Pension reforms adopted in the last decade will significantly reduce PAYG pension benefits for both current and (particularly) future pensioners. Tax relief for some retirement saving vehicles has been either capped by some amount or simply eliminated. Some of the major occupational private pension schemes were incorporated into Social Security. Recent studies demonstrate that public schemes, already running considerable funding deficits, continue to be unsustainable and will deliver inadequate income in retirement unless a significant increase in the coverage and funding levels of private pension schemes takes place (Bravo et al., 2013, 2014).

Personal tax and social security contribution systems play a role in old-age income support. Pensioners often do not pay social security contributions and receive preferential treatment under the income tax when compared to workers, either by giving additional allowances or credits to older people. The majority of OECD countries offer a favourable tax treatment to retirement savings made through private pension plans and other retirement saving vehicles. Often, individual contributions are fully or partially deductible from income-tax liabilities and investment returns are fully or partially relieved from tax. Some countries offer tax relief on pension payments. Pension taxation should contribute to create an adequate, affordable, sustainable, equitable and efficient pension system, comprising mechanisms for individuals and households to smooth consumption over time, to insure against (economic, financial, biometric) risks and to protect against the risk of poverty in old age. The question that

\footnotetext{
${ }^{2}$ Up to the 1989 reform, which introduced the PIT Code (CIRS), there was a schedular system of taxation.
} 
naturally emerges is then whether is there a taxation model with respect to public, private, occupational and personal pensions that complies with national constitutions and international tax agreements and contributes to deliver adequate retirement income, which generates neutral and equitable outcomes within generations and is financially sustainable in the long term.

This paper discusses the adoption of semi-dual income tax in the taxation of pensions, taking the Portuguese experience as a possible guide to other countries that may profit from this approach. The paper motivates and reviews the current semi-dual tax treatment of Portuguese pensions and other retirement income, highlights its particularities, and discusses whether it can contribute to the pension system long term goals and challenges. The arguments for and against the adoption of a semi-dual income tax in the taxation of occupational and private pensions and other retirement income are assessed, focusing on key issues such as the effects on the level and composition of saving, horizontal and vertical equity, intergenerational risk sharing, economic growth or fiscal and labour market outcomes. We highlight the key advantages and disadvantages of moving to a semi-dual income tax regime for pensions as compared to alternative tax regimes. We discuss the relative costs and benefits from recent pension tax reforms in Portugal, including their macroeconomic implications. We conclude that recent changes were not the result of a clear tax reform strategy but an outcome of economic, demographic, political and social circumstances.

Global competition provides strong incentives for countries to reduce tax rates, especially net borrowing countries like Portugal that are more dependent on foreign capital inflows. Providing separate tax rates for labour and capital income allows countries greater flexibility in addressing international tax competition and greater opportunity to retain and augment progressive tax rates for labour and pension income. Conversely, tax induced distortions (over the level and timing of saving and between different types of savings vehicles or assets) and arbitrage opportunities for income-shifting between categories should not be neglected. Although countries face much different economic, political, social and tax environments from those of Portugal or the Nordic countries, the semi-dual income tax may be an appropriate solution to the many challenges involved in the taxation of pensions.

The main contributions of this research are related to the characterization of pension's taxation in Portugal - as opposed to related studies, mainly focused on Nordic or Anglo-Saxon countries - as well as a detailed discussion on the relative merits of semi-dual tax systems in pension's taxation. The paper is organized as follows. Section 2 provides an overview of the Portuguese pension system, namely the structure of retirement-income provision and recent post-crisis pension reforms. Section 3 summarizes the characteristic features of a semi-dual income tax system and offers a detailed analysis of the current tax treatment of public, occupational and private pensions and retirement benefits in Portugal and how it compares in international terms. We pay special attention to social contributions levied on pension income and to a special personal income taxation regime for non-regular residents, particularly retirees. Section 4 discusses whether there is a theoretical or operational rationale for semidual income tax in the taxation of pensions, portrays the particularities of its implementation in Portugal, and analyses to what extent this option fits the long term goals and challenges of the Portuguese pension system. Section 5 summarizes our findings. 


\section{A Brief Overview of the Portuguese Pension System}

\subsection{Structure of retirement-income provision}

The Portuguese pension system combines a dominant mandatory PAYG earnings-related defined benefit public scheme, comprising two separate but convergent schemes, with incipient voluntary occupational and personal funded schemes, covering only $3.7 \%$ of country's workforce. The first PAYG scheme covers private sector workers and public servants registered after January $1^{\text {st }} 2006 .^{3}$ The second, closed to new entrants since January $1^{\text {st }} 2006$, covers contributors hired by the Public Administration before that date. ${ }^{4}$ The funded pillars are privately managed and provide benefits based on individuals' contributions and investment returns. Additionally, the public system includes non-contributory regimes which provide means-tested benefits. ${ }^{5}$ Figure 1 outlines the structure of retirement-income provision in Portugal. The participation in a public pension scheme is mandatory for most contract types and employment categories. ${ }^{6}$ Participation in the second and third pillar schemes is optional.

Figure 1 | Structure of retirement-income provision in Portugal

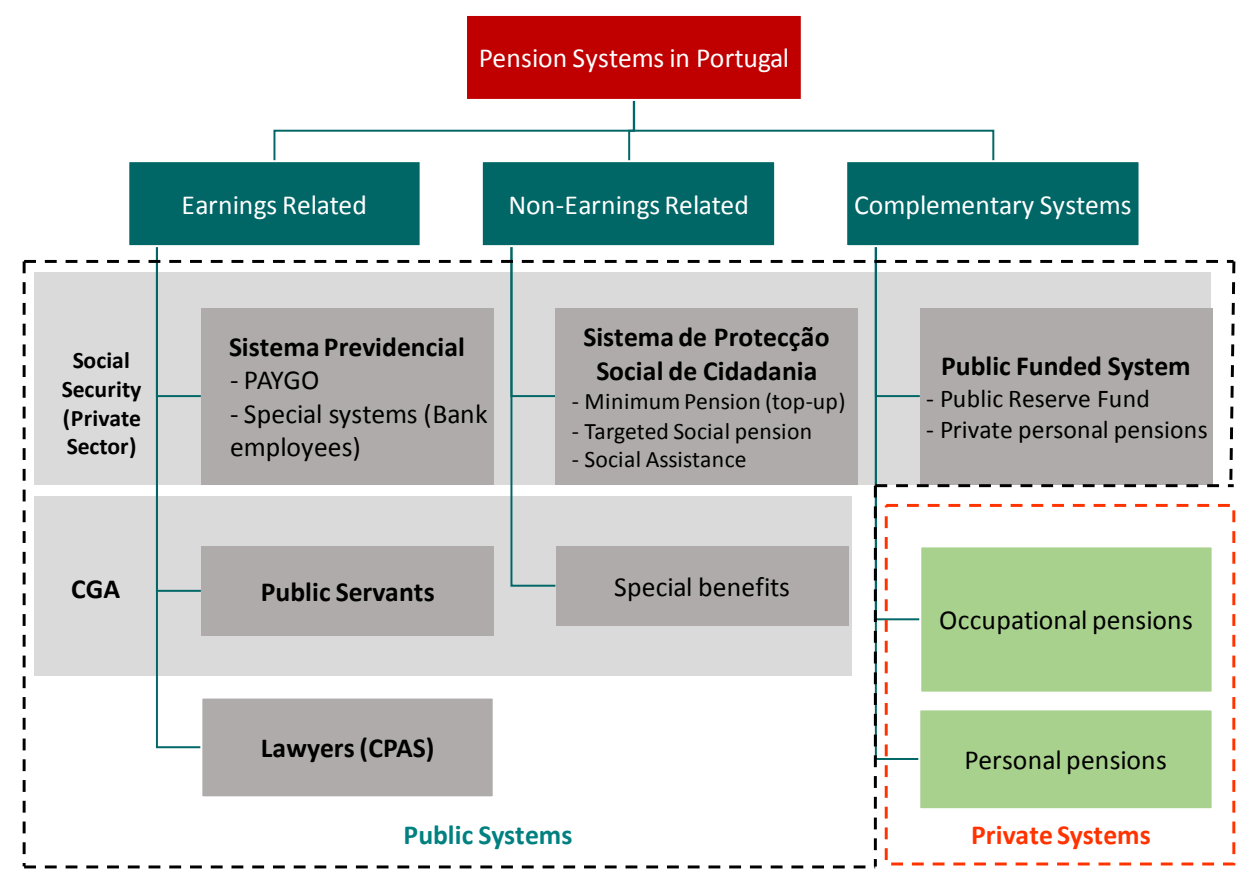

Source: Author's preparation based on Portuguese legislation.

Contributory (statutory) pensions are financed on a PAYG basis by social contributions, paid both by the employer and employee, complemented by a small fraction of the Value Added Tax (called Social VAT). The global contribution rate is currently set at 34.75 percent of gross earnings ( 23.75 percent to be paid by the employer and 11 percent by the employee), of which

\footnotetext{
${ }^{3}$ Subsistema Previdencial da Segurança Social.

${ }^{4}$ Sistema de proteção social dos funcionários públicos gerido pela Caixa Geral de Aposentações (CGA)

${ }^{5}$ An additional means-tested non-contributory old age benefit called "Contribuição Social para Idosos" has been created in 2006 to assist poorer old-age pensioners. The system also includes several targeted assistance programs aiming to reduce old-age poverty.

${ }^{6}$ The only exceptions are lawyers, solicitors and older bank employees who still have their own dedicated pension scheme.
} 
26.94 p.p. are earmarked for all types of pensions. ${ }^{7}$ For most self-employed, there is a compulsory flat contribution rate of $29.6 \%$, calculated on a percentage basis relative to real or conventional labour income. Contributions to second and third pillar schemes are elective, and separate from the regular social contribution. ${ }^{8}$ There is a Social Security (FEFSS) Trust Fund, managing currently around 14.000 million EUR in assets, that is financed through a fraction of Social Security contributions (when the system exhibits a surplus and/or the public finance stance is positive), that will act should SS treasury be under stress. ${ }^{9}$ The public funded scheme manages also a private pension saving scheme that sells, on a voluntary basis, retirement saving plans to workers seeking to build complementary income in retirement. Noncontributory means-tested pension benefits and top-up minimum (non means-tested) contributory benefits are fully financed by state transfers.

Public (and private) pension schemes grant old age, early retirement, disability and survivors pension benefits. The public old age pension is granted upon reaching the standard pensionable age (66 years in 2015) and the minimum contributory period (15 years). ${ }^{10}$ The complete contributory period, entitling to receiving full pension benefit, amounts to 40 years both for men and women. Early pension can be claimed at age 55 with at least 30 calendar years of contributions. ${ }^{11}$ Workers with hazardous jobs enjoy special retirement conditions provided the vesting period is completed.

The calculation of pensions is based on a DB formula. The benefit is calculated by multiplying the lifetime reference earnings (average monthly earnings for all years of coverage, up to 40 years) by an annual accrual rate ranging between $2 \%$ and $2.3 \%$ according to the insured's reference earnings. ${ }^{12}$ The lifetime reference earnings are adjusted according to the consumer price index (CPI), excluding housing. ${ }^{13}$ For early pensions, the total pension amount is reduced by $0.5 \%$ for each month the pension is received before the statutory age and, cumulatively, by

\footnotetext{
${ }^{7}$ The insured's and employer's contributions also finance sickness and maternity, occupational accidents \& disease, and unemployment benefits.

${ }^{8}$ There are special (minor) voluntary insurance schemes covering particular groups of individuals such as volunteers or scholarship researchers who pay a contribution rate of 23.5 percent or 29.6 percent, respectively. Up to now, there has been no salary ceiling. Members of Corporate Managing Bodies are in a completely separate category which contributes $29.6 \%$ (9.3\% from the individual and $20.3 \%$ from the employer) with a salary ceiling (12 IAS).

${ }^{9}$ Based on the most recent projections (Bravo et al., 2014), the fund will be depleted by 2024 unless additional tax transfers are made from the general budget to cover current and future expected deficits.

${ }^{10}$ A qualifying calendar year requires 120 days of registered pay. Calendar years with less than 120 days may be combined to complete a single year. Coverage periods under other domestic or foreign social security programs may be included with at least one calendar year of registered earnings under the general system. Old-age social pension (means tested) and solidarity supplement for the elderly can also be claimed at age 66 . The statutory retirement age is now linked to longevity increases. At the beginning of each year an adjustment is made that incorporates the ratio between the average life expectancy at age 65 in the first two of the previous three years and the base year of 2000.

${ }^{11}$ This option was suspended during the term of the "Troika" economic and financial assistance programme - from April 2012 until 2014 - except for the long-term unemployed. Unemployed workers aged 62 who are no longer entitled to receive unemployment benefits (or aged 57 with at least 22 calendar years of contributions at age 52) can ask for a full (reduced) pension. The pension may be deferred until age 70 .

${ }^{12}$ For a transitional period, pensions are calculated according to the previous method ( $2 \%$ of average annual earnings for the best 10 calendar years out of the last 15 years multiplied by the total number of qualifying calendar years) or the current lifetime reference earnings method.

${ }^{13}$ In calculating lifetime reference earnings, the annual earnings registered after 1 January 2002 are adjusted by applying an index resulting from the weighting of $75 \%$ of the $\mathrm{CPI}$, and $25 \%$ of the average evolution of the earnings which underlie the contributions stated to the social security, whenever this evolution is higher than the CPI. The annual adjustment index cannot, however, be higher than the CPI plus $0.5 \%$.
} 
a demographic factor. This so-called "sustainability factor» is defined as the ratio of (unisex) life expectancy at age 65 observed in 2000 (previously 2006) to life expectancy at age 65 recorded in the year before the pension claim. Deferred pensions are increased for each additional calendar month of contributions from the retirement age to 70 (the bonus ranges between $0.33 \%$ and $1 \%$ per month). ${ }^{14}$ Minimum benefits for contributory pensions are defined by law accordingly to the length of contribution careers. The difference between actual statutory pension and the minimums (social supplements) are financed by state transfers without any means-testing. Old-age pensions may be cumulated with labour earnings except if the pension is a result of the replacement of a previous (total) disability pension. ${ }^{15}$ In 2014 there were 3.627 million contributory pensions in the public earnings related schemes. Total public pension expenditure, consisting of old-age, disability and survivors pensions paid from the several earnings and non-earnings related schemes, accounted for $15.7 \%$ of GDP and almost $75 \%$ of all social security expenditure. Average annual old-age pension amounts to EUR 5.098 (16.111) for those in the private (public) sector. The current (2014) benefit ratio is 70,8\% $(54,9 \%)$ for male (female) pensioners, but is projected to decline significantly as a result of recent pension reforms and pension indexation rules that do not fully share productivity gains.

Occupational pensions are not very widespread in Portugal. By law, they may be set up at the initiative of a company, and groups of social or professional associations and take the form of closed and open pension funds or pension insurance contracts (collective insurance). Pension schemes funded through collective membership of an open pension fund may be of different types: DC, DB or hybrid schemes, and they may also be contributory. Contributions to occupational pension plans are mostly employer contributions. Employee contributions to these plans are not impossible, but not common. In the past, pension funds used to be concentrated in the banking and utilities (telecom, electricity, gas, water) sectors, particularly within former public companies. Benefits are in the form of lump sum/commutation (maximum 1/3) and annuity payments. Although the saving rate is low (c.a $4.2 \%$ of families disposable income in 2015), private pension saving schemes exist in the form of individual acquisition of open pension units (Fundos de Pensões Abertos), pension insurance retirement contracts (Fundos Poupança Reforma), Personal Retirement Saving Funds, financed through insurance contracts, pension funds or investment funds, and Equity Savings Plans (Fundos Poupança Acções). Some were very popular in the past due to their generous tax incentives.

\subsection{Recent post-crisis pension reforms}

In recent years Portugal has implemented numerous (temporary and permanent) parametric pension reforms aiming to reduce public pension expenditure with little margin to address income adequacy concerns in an already highly aged society. In the aftermath of a major economic crisis, economic recession, unsustainable government debt, excessive public pension expenditure, significant macroeconomic imbalances, a rising share of older people in the total

\footnotetext{
${ }^{14}$ The minimum pension is either $30 \%$ of the reference earnings used for pension calculation or a fixed monthly amount according to the number of calendar years of contributions (ranging from €259.36 with up to 15 calendar years of contributions to $€ 379.04$ with at least 31 years), whichever is greater. The maximum pension is $92 \%$ of the reference earnings.

${ }^{15}$ For the contrary, an early retirement pension may not be accumulated with labour earnings during the first three years after the date of access to the old-age pension, whenever that income is a result of any activity or work undertaken in the same company or group where the beneficiary was working.
} 
population and the signing and implementation of a bailout assistance program in 2011, the main policy initiatives were driven by the short-term need for fiscal consolidation rather than by a long-term prospect for the design of pension systems.

Following the approval of the new Social Security Framework Law in 2007, a number of parametric reforms were introduced, among which we highlight: (i) the inclusion of a demographic (sustainability) factor in the pension formula based on life expectancy at age 65, reducing the value of the initial pension for all new pensioners; ${ }^{16}$ (ii) bringing forward the new pension formula that changes from best 10 out of last 15 years to lifetime average earnings; (iii) a new indexation mechanism linked to prices and real GDP growth (suspended between 2010 and 2016) to moderate pension expenditure; (iv) the introduction of bonuses (penalties) for late (early) retirement; (v) Harmonization of public pension schemes benefit rules; (vi) revision of the criteria for means-testing for non-contributory benefits.

The signature of the bailout assistance agreement in 2011 would bring about important changes to the Portuguese pension system, some temporary, others permanent. First, the statutory retirement age has been increased to 66 years for both men and women in 2014 and is now linked to longevity increases observed at age 65 . Second, the demographic factor definition has changed to consider the year 2000 as the reference year, thus increasing the penalty for early retirement, but applies now only to those claiming early an old-age pension or when converting invalidity pensions into old-age pensions, and not to all pensioners as before. Third, workers in the banking sector recruited after March 2009 are now automatically covered by the public pension scheme. Fourth, early retirement regimes were suspended, with the exception of long-term involuntary unemployment. Fifth, the 13th and 14th monthly payments to pensioners with incomes of more than EUR 1100 per month were temporarily eliminated and, with the exception of minimum non-contributory pensions (e.g. rural and social pensions), pension benefits were nominally frozen. Sixth, new rules for the management of FEFSS were approved in order to ensure liabilities are appropriately hedged and some investment flexibility is maintained. Seventh, a significant fraction of assets (and liabilities) in bank employees funded pension systems were transferred to social security. Finally, at the fiscal level the main changes included both permanent measures (e.g. higher personal income withholding tax rates and lower specific deductions applying to pension income) and temporary measures (e.g. the Extraordinary Solidarity Surcharge - CES and the Personal Income Extraordinary Surcharge), that will be detailed below. Following the end of the bailout assistance period in June 2014, there were proposals to transform some of the temporary measures into permanent ones, but they were overruled by the Constitutional Court.

Despite all restrictive parametric measures implement in recent years, long-term independent projections show that the systems will continue to exhibit permanent deficits and that the level of pension expenditure remains unsustainable and will deliver inadequate income in retirement (Bravo et al., 2013, 2014). Consolidation measures considered unconstitutional were not replaced and a more comprehensive and structural pension reform was abandoned, waiting for "political consensus", that is now less likely following the outcome of recent legislative elections.

\footnotetext{
${ }^{16}$ This factor results from the relation between the average life expectancy at age 65 in 2000 (previously 2006) and the one recorded in the year before the pension claim.
} 


\section{Taxation of Pensions in Portugal}

In this section we provide a detailed analysis of the current tax treatment of pensions and retirement benefits in Portugal and how it compares in international terms. We describe separately the tax treatment of contributions, returns on investments and accumulation of funds and pension income in public and private (personal and occupational) pension schemes, life insurance contracts, mutual funds and alternative saving for retirement vehicles. We pay special attention to social contributions levied on pension income and to a special personal income taxation regime for non-regular residents, particularly retirees. Before that, in order to highlight the special features of the semi-dual income tax system we briefly discuss the main alternative approaches to taxing pension income. ${ }^{17}$

\subsection{Basics of Pension Taxation Regimes}

The taxation of pensions involves three cash flows that can be taxed and the timing of taxation. Pensions can be (totally or partially) taxed (T) or exempt (E) at the point when employees and employers contribute or save to the pension scheme or savings vehicle, when asset returns (interest, capital gains or the equivalent gains in a PAYG system or distributable profit) arise or when pension income is withdrawn. In addition, corporate income tax, regional taxes, inheritance taxes, regular or extraordinary surcharges and other taxes (e.g., property taxes, stamp duties) may directly or indirectly affect pension returns and consideration therefore needs to be given as to whether the tax treatment of pensions at the personal level should reflect this. Given the three possible cash flows and accruals and timing points at which it is possible to charge taxes, a wide range of tax regimes can be found internationally. Additionally, in most countries it is quite common to find, at the national level, different tax treatments depending on the type of plan, the way it is financed, the nature of contributions (mandatory or voluntary) or the contribution sources (employer, individual, both).

In a pure Schanz-Haig-Simons (SHS) comprehensive income tax system, all (or most) changes in the net asset (including labour, pension and capital income) are added up and subjected to a common (usually) progressive tax schedule. The system is based on the idea that all of the taxpayer's income-regardless of its form-should be taxed once (and only once) and in the same manner. This is in contrast to a "schedular" tax system, where different types of income are taxed separately ${ }^{18}$. Accordingly, savings made out of taxed earnings and accrual returns on accumulated funds (including the revaluation of pension entitlements in PAYG schemes) are also subject to an income tax. In return, the withdrawal of assets from such saving vehicles is fully exempted from taxation. Such arrangements are known as "Taxed-Taxed-Exempt" (TTE) schemes. Assuming that annual comprehensive income is a socially acceptable indicator of a citizen's ability to pay ${ }^{19}$, SHS tax systems ensure horizontal equity (taxpayers with the same level of annual income are taxed equally) and, for a given consensus about the redistributive features of the system, properly graduated tax scales also ensure vertical equity (taxpayers with higher incomes are taxed more heavily). This method of taxation discriminates in favour

\footnotetext{
${ }^{17}$ For a detailed analysis on the main approaches to taxing personal income see, e.g., OECD (2006).

${ }^{18}$ This type of tax system usually involves significant tax allowances and tax exemptions, whose value to taxpayers increases with income.

${ }^{19}$ A measure that makes it more difficult to escape taxes through income shifting between categories.
} 
of current consumption, particularly in high inflation scenarios, i.e., it is not neutral with regard to present and future consumption and acts as a disincentive to (particularly long term) saving.

In a pure Fisher-Kaldor-Meade (FKM) expenditure (consumption, cash-flow) tax regime, only consumption (not saving and capital income) is taxed. Accordingly, both funds contributed and investment returns are tax exempted. In return, the benefits are treated as taxable income upon withdrawals and, thus, taxation is deferred to the payout phase. This is known as an EET (Exempt, Exempt, Taxed) regime or tax deferral regime (tax is deferred until the point in time when people withdraw benefits). An EET base can be thought of as giving tax relief for saving up front and is thus equivalent to saving in a tax-deferred account. Contrary to SHS tax systems in which present consumption is taxed at a lower rate when compared to future consumption, EET systems achieve fiscal neutrality between current and future consumption since all savings are tax-exempt. EET system allows taxpayers more freedom to smooth consumption over their life cycle. This is the most common tax treatment of saving in PAYG and funded private pension plans at the personal level across industrialised countries (Yoo and Serres, 2005; Wellisch et al., 2008; OECD, 2015). The higher the returns generated by the saving vehicle, the greater will be the amount of tax paid on pension income. An EET regime allows tax-rate smoothing over the lifetime and may create incentives to save for retirement. Specifically, under a pure EET system individuals who are higher (lower)-rate income tax payers during their working life but who expect to be lower (higher)-rate income tax payers in retirement will face a stronger incentive to save (not to save) for retirement.

Under a prepaid expenditure tax model, pension contributions are made out of (totally or partially) after-tax income, no income tax or capital gains tax is levied on returns as they accrue in the saving vehicle, and withdrawals from the pension scheme or saving vehicle are not subject to income tax. This is known as a TEE (Taxed, Exempt, Exempt) regime or tEE when contributions are partially exempt (through tax deductions or tax credits). This system provides a distortion towards future consumption among those individuals who expected to be able to generate high returns from investment since they will pay no further tax. The tax incentive to save for retirement provided by EET and TEE regimes over TTE and ETT regimes comes from the non-taxation of the returns on investments.

As a compromise between the progressive comprehensive income tax, which levies one tax schedule on the sum of income from all sources, and the expenditure tax, which avoids taxing capital income altogether, several countries have adopted a dual income tax (DIT). The key distinction in a DIT system is that between capital income and other income. The DIT is a particular form of schedular tax that applies a separate (generally lower ${ }^{20}$ ) flat tax rate to capital income and a progressive tax schedule to the sum of the taxpayer's income from other sources (e.g., labour and pension income). Tax credits and deductions are used to enhance horizontal and vertical equity. ${ }^{21}$ Under a pure DIT, capital income would include interest, dividends and capital gains from financial assets, imputed rent on housing, accrued returns on pension savings, and profits from personal businesses. Corporation and personal income tax

\footnotetext{
${ }^{20}$ In the pure form of the DIT, the personal tax rate on capital income is aligned with both the corporate income tax rate and the marginal tax rate on labour and pension income in the first bracket.

${ }^{21}$ The introduction of a lower proportional tax rate on capital income might undermine the vertical equity, especially because income from capital tends to be concentrated in the upper income brackets.
} 
rates are fully integrated using imputation or some other method. ${ }^{22}$ Given the large difference in the marginal tax rates on capital and labour income, the dual income tax provides medium and high income self-employed individuals with large incentives to participate in tax minimizing income shifting.

Semi-dual and semi-comprehensive income tax systems are systems in which different nominal tax rates are levied on different types of income. Contrary to DIT that establish a level playing field for capital investment by taxing all capital income at the same flat tax rate, a semi-dual income tax (SDIT) system is a particular form of schedular tax that applies different flat rates to some forms of capital (personal or corporate) income, while maintaining a progressive tax schedule on other sources of income. Semi-dual income tax systems tax most types of capital income at rates that deviate from the progressive tax rates on labour and pension income. Semi-comprehensive income tax systems tax most types of capital income at high and often progressive rates which are levied on labour income as well. Dual Progressive Income Tax (DPIT) system taxes capital income separately from labour income but capital income is taxed at modestly progressive tax rates.

Finally, under a flat tax system a proportional (flat) tax rate is levied on all net income (capital income, labour income, and other income minus all deductions). Labour and capital incomes are taxed equally and the value of the tax allowances is, in some cases, independent of the income level, thus limiting the scope for a fair sharing of the tax burden. In countries in which social security contributions are levied only on labour income (and not, for instance, on capital income), delivering a flat pension benefit undermines the uniformity of the system and is not consistent with actuarial fairness. Progressivity in these types of systems is accomplished through basic income provision. If the same flat rate is introduced for personal and corporate income tax this reduces tax incentives for income shifting.

\subsection{Taxation of public pensions}

The general taxation regime of public pension schemes in Portugal may be classified as EET for employees and employers. Employer and employee contributions to public pension schemes are not taxed. Employer contributions are considered part of the payroll, and therefore deductible in computing the corporate income tax (CIT), whereas employee contributions are deductible for personal income tax purposes. Tax relief is unlimited and applied at the individual's/family marginal income tax rate. There are different contribution rates for specific groups of workers.

Public pensions are funded on a PAYG basis and partially financed from the general government budget (non-contributory benefits) and, hence, there are no returns on investments that could be subjected to, or exempted from, taxation. Notional capital (i.e. increases in pension entitlements through the revalorization mechanism of contributions, indexed to productivity gains and inflation) are entirely tax-free. On the tax treatment of pensioners, public pensions are considered as deferred labour income and treated as pension income and taxed at the individual's marginal income tax rate. The first EUR 4104 of annual pension income is tax exempt (deducted from the tax base) regardless of its source. However,

\footnotetext{
${ }^{22}$ For capital losses, there are two main options: offsetting capital losses against positive labour income in the same period, or offsetting capital losses by a tax credit which can be deducted from the labour tax bill.
} 
an extraordinary solidarity contribution (Contribuição Extraodinária de Solidariedade), socalled CES, introduced in 2011 and expanded as part of the "Troika» bailout program ${ }^{23}$, is paid on pensions above a certain amount. At its inception, CES applied also to private pensions and annuities paid by occupational pension plans.

According to the Portuguese Personal Income Tax (PIT) system, Portuguese residents are taxed through IRS (Personal Income Tax) on their worldwide income on a self assessment basis and non-residents are subject to Portuguese tax on their Portuguese-sourced income at the applicable rates. ${ }^{24}$ Income is split into 6 categories ${ }^{25}$ and defined general and specific tax deductible expenses are subtracted (with specific limits) from gross income for each category to arrive at the net taxable income for the category. To limit unintended distribution to highincome families, starting in 2015 tax deductible expenses are now capped by an incomerelated global tax deduction amount. ${ }^{26}$

The net incomes for each category are then added together in order to arrive at a total net income. Income from self employment is taxed either under a 'simplified regime' or based on the taxpayer's actual accounts. An apportionment/splitting procedure applies to married couples by dividing the family income by a family coefficient before the applicable marginal tax rate is determined. The calculation of the family quotient depends on the number of dependants and ascendants, but the application of the quotient cannot result in a reduction of the taxable income exceeding given thresholds. In other words, in Portugal the ability to pay principle is sensitive to family dimension. Total taxable income is subject to highly progressive tax rates (Figure 2), but contains a substantial zero-bracket amount that resulted in only relatively high levels of labour income being subject to the higher progressive tax rates. ${ }^{27}$ As of 2015, there are 5 income bands with tax rates ranging from 14.5 to 48 percent (11.6 to 38.4 percent in the Azores islands). This version of a dual income tax is equivalent to a flat tax on all income with a surcharge on labour income above a certain threshold.

A 3.5\% additional surcharge for PIT was introduced in September 2011 and is levied on annual taxable income (including pension income) exceeding EUR 7070. For taxpayers in the top bracket, a 2.5 percent Additional Solidarity Surcharge will be levied on taxable income between EUR 80000 and EUR 250000 and 5 percent on the taxable income exceeding EUR

\footnotetext{
${ }^{23}$ On May 2011, Portugal agreed with the European Union and the International Monetary Fund on a far-reaching reform programme to restore market confidence and raise potential growth. The three-year programme was backed by substantial international financing (around EUR 78 billion) and had three main goals: i) implement a credible fiscal consolidation supported by structural fiscal measures and better fiscal control over public-private partnerships (PPP) and state-owned enterprises (SOE); ii) safeguard the financial sector against disorderly deleveraging through market-based mechanisms supported by backed-up facilities; and iii) implement deep structural reforms to boost potential growth, create jobs, and improve competitiveness (including through fiscal devaluation). The programme was successfully concluded in mid 2014.

${ }^{24}$ A double taxation treaty may provide a variation to these rules. As of 1 January 2015, the general rule is that married couples are taxed separately, and the personal income tax due will be assessed individually. However, both married couples and living together couples have the option to be taxed jointly.

${ }^{25}$ Employment income, self-employment income (derived from carrying out any commercial, industrial, or agricultural activity), investment income (including interest and royalties), rental income, capital gains and pensions. ${ }^{26}$ For annual taxable income (RC) exceeding EUR 7000 but below EUR 80000 the limit for tax deductions ranges between EUR 2500 and EUR 1000 according to the formula $1000 €+\left[(2500 €-1000 €) \times\left(\frac{80000 €-R C}{80000-7000 €}\right)\right]$. For an annual taxable income above EUR 80000 the maximum deduction available is only EUR 1000.

${ }^{27}$ Families with annual income below $€ 8.480$ are PIT exempted. In 2015 , about 2.5 million pensioners (circa $83 \%$ of total) will be exempt from PIT.
} 
$250000 .^{28}$ The progressivity of the tax system and the overall tax burden of households, particularly retirees, have significantly increased in recent years as a result of the 2013 PIT tax reforms that reduced the number of tax brackets, increased marginal tax rates and created surcharges. Starting in 2015, labour and pension income are treated equally, with the same PIT rates and deductions. In international comparison, the income threshold for the top bracket is one of the highest in OECD countries (together with Sweden and Denmark) and the marginal tax rate at that income level is quite closer. With an average tax wedge on labour income of $41.22 \%$ in 2014, Portugal is still well above OECD (35.96\%) and EU averages and with little room for further tax increases.

Figure 2 | Marginal tax rates by taxable income in Portugal, as of January 12015

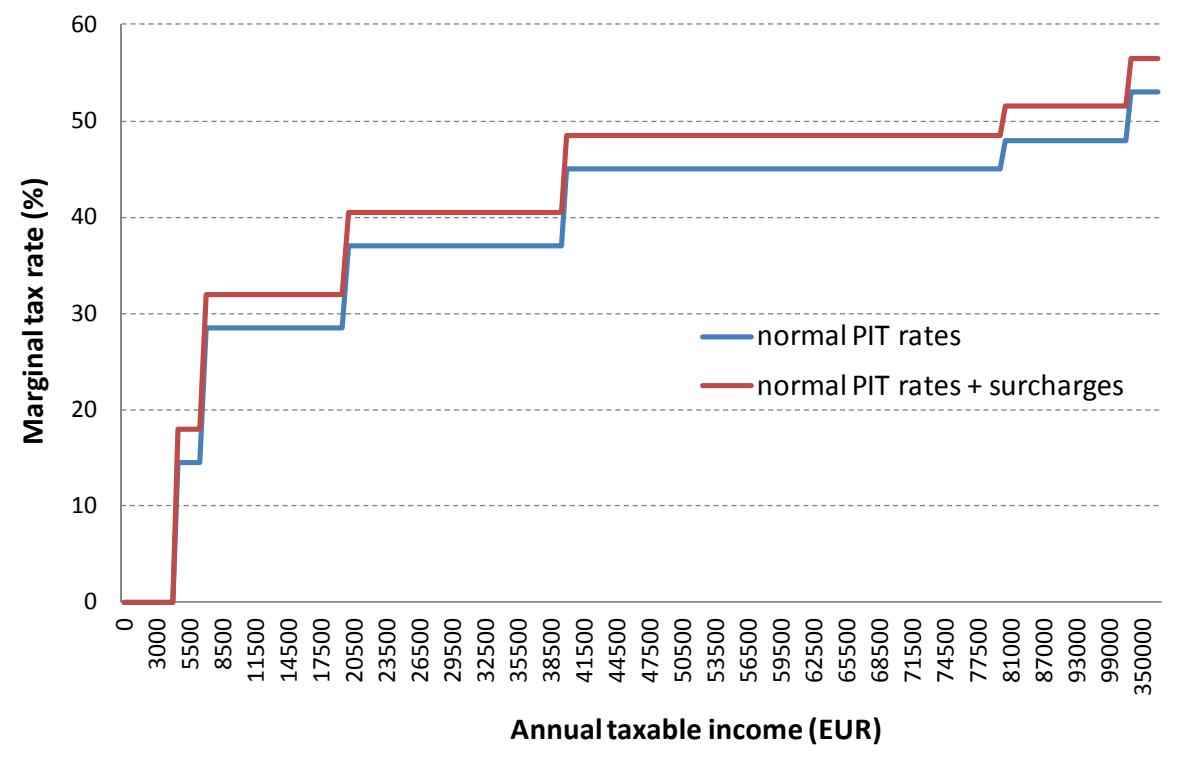

Source: Author, based on Portuguese legislation.

Recent tax reforms promoted a systematic differential treatment of investment income from income derived from other sources by using a common proportion tax. To enforce horizontal equity, tax rules were simplified and systematized by the use of proportional rates. To create a unified system that respects differences in the international mobility of income, tax rates applicable to income earned by residents and non-residents were made equal, with the exception of the regime for non-habitual tax residents detailed below. ${ }^{29}$ The semi-dualization of the system aims to promote simplicity and stability. The general taxation regime of public pension schemes in Portugal is the most common one in OECD countries (Table 1). Many OECD and EU countries apply a variant of the EET regime to public pensions, with contributions and returns on (real or notional) investment totally or partially taxed.

\footnotetext{
${ }^{28}$ Pension and employment income is subject to a monthly withholding tax. Any tax withheld is considered to be a payment on account against the final total tax liability.

${ }^{29}$ For non-residents, labour, business and professional income is taxed at a uniform rate of 25 percent. Interest, dividend, capital gains on the sale of shares and rental income are taxed at a uniform rate of 28 percent, but can be exempt in some particular circumstances. Pension and capital gains on the sale of real estate are taxed progressively at the marginal rates up to 48 percent, but can be exempt in some cases.
} 
Table 1 | Overview of the taxation of public mandated and unfunded pensions in OECD countries, as of 2013

\begin{tabular}{|c|c|c|}
\hline Tax regime & Country & Pension taxation regimes \\
\hline E-E-T & $\begin{array}{l}\text { BE, DK, EE, FI, GR, IT, LT, LU, AT, } \\
\text { PO, SE, CH, SI, ES, CZ, CY, PT }\end{array}$ & $\begin{array}{l}\text { Expenditure tax model, pension benefits treated } \\
\text { as "deferred labour income" }\end{array}$ \\
\hline$t-E-T$ & $\mathrm{FR}, \mathrm{IR}, \mathrm{CA}, \mathrm{MT}, \mathrm{NL}, \mathrm{UK}$ & $\begin{array}{l}\text { Deferred comprehensive income tax model with } \\
\text { double taxation relief }\end{array}$ \\
\hline$t-E-t$ & DE, US & Fragmented expenditure tax model \\
\hline T-E-E & $\mathrm{LI}$ & $\begin{array}{l}\text { Tax-free savings accounts, } \\
\text { "prepaid expenditure tax model“ }\end{array}$ \\
\hline$E-E-E$ & $\mathrm{SK}, \mathrm{HU}$ & Full income tax exemption \\
\hline T-T-E & None & Comprehensive income tax model \\
\hline
\end{tabular}

Source: Author, based on OECD Pensions at a Glance 2013 and Wellisch et al. (2008).

\subsection{Taxation of occupational and personal private pensions}

In Portugal, contributions from employers and employees and returns on investments within the same type of plan are often treated differently in the income tax system. The tax treatment varies according to the type of plan in which the individual is a member and pension income can be treated differently according to the payout option and income nature (capital, return on capital). There are limits to the amount of contributions attracting tax relief (defined, for instance, as a proportion of the individual's income and age) and plan members may be eligible for tax relief if the plan complies with certain rules. With the exception of CES, social contributions are not levied on private pension income.

The general taxation regime of voluntary occupational and personal private pension schemes in Portugal may be classified as TET for employee or individual contributions and EET for employer contributions. The tax treatment for direct insurance schemes is the same as for pension funds. Employer contributions are fully deductible in computing the CIT if the plan provides individualized acquired right's benefits. ${ }^{30}$ If the pension plan benefits are "mere expectations" and a number of conditions are fulfilled ${ }^{31}$, employer contributions are deductible in computing the CIT up to $15 \%$ of the annual total costs with wages and salaries ${ }^{32}$. If the contributions exceed the above limit, the exceeding part is not deductible for CIT purposes unless the amounts are included in the employee's taxable income. Social contributions are not levied on employer pension contributions. A flat $\mathrm{CIT}$ rate of $21 \%$ is levied on the global taxable income realised by companies resident for tax purposes in Portugal (also

\footnotetext{
${ }^{30}$ All permanent workers of the company must be enrolled in the pension plan and benefits are established in accordance with objective criteria applying to all in the same way.

31 At least $2 / 3$ of the benefits must be annuitized and the provisions of the general social security scheme are accompanied with regard to retirement age, the pension plan assets are not managed by the sponsor, the pension plan covers exclusively benefits in case of retirement, health (post-work), disability or survivorship.

${ }^{32}$ The limit is $25 \%$ if employees are not covered by social security.
} 
applicable to Portuguese PEs of foreign entities) ${ }^{33}$. A reduced $\mathrm{CIT}$ rate of $17 \%$ applies to small and medium-sized companies on the first 15000 EUR of taxable income.

Regarding employee contributions, if the plan provides individualized acquired right's benefits $20 \%$ of overall employee contributions to private pension plans (both occupational and personal) made prior retirement are tax deductible, up to a limit which varies according to the individuals' age. ${ }^{34}$ In addition, the above mentioned income-related global tax deduction amount applies. If the pension plan delivers benefits that are considered mere expectations there are no tax deductions and a tax deferral regime applies. Regarding the tax treatment of returns on investments and accumulation of funds, the general rule is that income generated by private pension assets is tax exempt. Dividends, rental, interest and other capital income are VAT exempt. Pensions funds are also partially exempt of property, municipal and stamp duty. Concerning the tax treatment of accumulation of funds, there is no ceiling on the lifetime value of private pension funds. No tax applies on accumulation of funds

The tax treatment of private pension income depends on whether or not contributions were tax exempt and on the type of payout option (annuities, lump sum). Taking benefits as programmed withdrawals is not allowed in Portugal. If the plan provides individualized benefits (contributions were exempt) and the payout option is in the form of annuities, pension income is taxed at the individual's PIT rates. A maximum deduction of EUR 4104 applies to total pension income. However, if the compulsory contributions to social protection schemes and to legal health subsystems exceed that limit, the deduction will be equal to the total amount of contributions. If contributions were tax exempt and pensioners choose to take accumulated capital as a lump sum, until December 31, 2014 one-third of the "contribution part" (capital component) is tax-exempt up to a maximum of EUR 11704,70 . From that date on, the tax exemption has been eliminated. The remainder is taxed at the individual's PIT rates. The capital gain and other return on the investment part are taxed at an autonomous rate of $4 \%$ or $8 \%$ depending on whether the contributions that originated such income were made before or after the 1st of January 2006 respectively.

If contributions were taxed and the payout option is in the form of annuities, the contributions component of the accumulated pot is exempt, and only the capital gain and other returns on the investment component is taxed at the marginal PIT rates. ${ }^{35}$ If contributions were taxed and pensioners choose to take accumulated capital as a lump sum, the contributions component is exempt, whereas capital gain and other returns on the investment part is taxed at an autonomous rate of $4 \%$ or $8 \%$ depending on whether the contributions that originated such income were made before or after the 1 st of January 2006 , respectively. ${ }^{36}$ With the exception of CES, social contributions are not levied on pension income. ${ }^{37}$

\footnotetext{
${ }^{33}$ A lower CIT rate of $18.4 \%$ applies to companies that are tax resident in the Autonomous Region of Azores, including PEs of foreign entities registered therein.

${ }^{34}$ Tax deductions are EUR 400 per taxpayer under 35 years old, EUR 350 per taxpayer between 35 and 50 years old, and EUR 300 per taxpayer above 50 years old.

${ }^{35}$ If it is not possible to distinguish between contributions and returns, then only $15 \%$ of the annuity is subject to taxation at the marginal PIT rates.

${ }^{36}$ The amount of interest income subject to taxation can be reduced if more than $35 \%$ of the contributions are paid in the first half of the contract, and the benefits are received more than 5 years after the beginning of the contract
} 
Comparing the taxation of private pension plans in Portugal with that of their international counterparts, we observe that while Portugal applies a TET regime for employee or individual contributions and EET for employer contributions, many OECD and EU countries apply a variant of the EET regime (Table 2). Six other tax regimes can be found among other OECD and EU countries. Returns on investment are taxed in seven countries. In Denmark, Italy and Sweden returns on investment are however not subject to progressive income tax rates but rather to flat tax rates. In the particular case of Italy, returns on investment are not subject to double taxation during the accumulation and decumulation phases. In the Slovak Republic and Bulgaria, mandatory contributions to personal pension plans into which part of social security contributions are paid enjoy an EEE tax regime. ${ }^{38}$

Table 2 | General tax treatment of private (occupational and personal) pension plans in OECD and non-OECD countries, as of 2015 or the latest year with available data

\begin{tabular}{|cll|}
\hline Tax regime & \multicolumn{1}{c|}{ OECD countries } & Non-OECD countries \\
\hline EET & $\begin{array}{l}\text { Canada, Chile, Estonia, Finland, Germany, Greece, Iceland, } \\
\text { Ireland, Japan, Netherlands, Norway, Poland, Slovenia, } \\
\text { Spain, Switzerland, United Kingdom, United States }\end{array}$ & Croatia, Latvia, Romania \\
\hline TEE & Czech Republic, Hungary, Mexico & Lithuania \\
\hline ETE & & Cyprus \\
\hline TET & $\begin{array}{l}\text { Austria, Belgium, France, Israel, Korea, Luxembourg, } \\
\text { Portugal }\end{array}$ & Malta \\
\hline ETT & Denmark, Italy, Sweden & Bulgaria \\
\hline TTE & Australia, New Zealand, Turkey & \\
\hline EEE & Slovak Republic & \\
\hline
\end{tabular}

Source: OECD (2015).

At the EU level, the European Commission has been trying to remove tax obstacles to a Single Market for occupational pensions and supports deferred taxation regimes on the grounds that contributions to pension funds diminish a person's ability to pay taxes, this taxation model encourages individuals to save for retirement and it will help Member States to deal with an ageing population, since tax revenues are expected to be higher at a time when more elderly people are likely to call on social policies for care.

\subsection{Taxation of investment income and capital gains}

Portuguese residents are subject to PIT on all their investment income. For certain types of Portuguese or foreign-sourced investment income, residents may choose between being taxed

( 5 to 8 years: $80 \%$ of the interest is taxed; more than 8 years: $40 \%$ of the interest is taxed). Otherwise, an autonomous normal $21.5 \%$ rate is levied on interest income subject to taxation.

${ }^{37}$ The interest income subject to taxation can be reduced if more than $35 \%$ of the contributions are paid in the first half of the contract, and the benefits are received more than 5 years after the beginning of the contract (5 to 8 years: $80 \%$ of the interest is taxed; more than 8 years: $40 \%$ of the interest is taxed). Otherwise, an autonomous normal $21.5 \%$ rate is levied on interest income subject to taxation.

${ }^{38}$ For a detailed analysis of the tax treatment of contributions, returns on investment and pension income by country, between different types of plans, different types of contributions (i.e. mandatory or voluntary) and different sources of contributions (i.e. employer or individual) see OECD (2015). 
at reduced withholding tax rates, or adding to the overall income and be taxed according to the general PIT rules. Interest from bank deposits in Portugal, interest on Portuguese bonds, dividends paid by Portuguese companies and dividends and interest paid by foreign entities may be excluded from overall income and be taxed at a flat withholding rate of 28 percent. Contrary to the so-called "pure" version of the dual income tax, the tax rate on capital income is not aligned with the CIT rate. Non-residents are subject to PIT on their Portuguese-sourced investment income through withholding at the same withholding flat rates. ${ }^{39}$ Capital gains arising from the difference between an asset's sale value and the corresponding acquisition cost are, in the case of shares, fully taxed at a $28 \%$ special rate. ${ }^{40}$ Capital gains relating to immovable property acquired after 1 January 1989 are assessed to tax at progressive rates on $50 \%$ of their value. ${ }^{41}$ As to land for construction, it is subject to tax irrespective of the date of acquisition. Capital gains on the sale of unlisted equity of micro and SME companies are only taxable in $50 \%$. Portuguese residents are subject to PIT on the capital gains relating to Portuguese and/or foreign assets. Non-residents are only subject to PIT on their Portuguesesourced capital gains relating to immovable property. Property Rental Income is subject to tax at a $28 \%$, or added to other categories of income after deducting all maintenance and repair expenses and Municipal Property Tax (IMI). There are no wealth, inheritance and gift taxes in Portugal. There are no property taxes in Portugal, other than IMI.

\subsection{Taxation of Investment Funds income}

Investment funds benefit from a favourable tax treatment in Portugal based on the principle that the holder of the units will have the same tax treatment than if it had invested directly in the assets held by the fund. From 1 July 2015 onwards, Collective Investment Vehicles (CIV) established and operating according to Portuguese law are taxed on profits, being however exempt, among others, investment income, rental income and capital gains, unless that income derives from "offshore" entities. Tax losses generated by CIV now follow the regime foreseen in the CIT code. The taxable income is subject to the general CIT rate. Municipal and state surtax are not applicable. With proper adjustments, autonomous taxation is also applicable. Stamp tax rates range between 0.0025 and 0.0125 percent. The taxation "at exit" rule is applicable to the taxation of income obtained by individual holders of participation units/shareholdings in the CIV. For individual investors resident in Portugal for tax purposes ${ }^{42}$, income distributed by the CIV and gains on the redemption are subject to a definitive flat withdrawal holding tax (WHT) rate of 28 percent, unless investors opt to be taxed on their overall income. Net capital gains are taxed at a WHT rate of 28 percent. For corporations, income distributed by the CIV is subject to WHT at a flat rate of 25 percent. Capital gains are not subject to WHT, as they are included in annual taxable profit. With some exceptions,

\footnotetext{
${ }^{39}$ Investment income paid by non-resident entities without a permanent establishment in Portugal, domiciled in jurisdictions with more favourable tax regimes, is liable to an autonomous tax rate of $35 \%$.

${ }^{40}$ Realized capital gains are included in taxable profits for corporate tax purposes, but gains on the disposal of shares may be exempt from tax under Portugal's "participation exemption regime".

${ }^{41}$ For non-residents tax is assessed on 100 percent of the capital gain at a $28 \%$ autonomous rate.

42 Income distributed by the CIV to individuals and corporations non-resident in Portugal for tax purposes and gains arising from the redemption of units/participations are subject to lower flat tax rates and/or is tax exempt.
} 
foreign investment funds are only taxed on income obtained in Portugal at a WHT tax at a rate of 25 percent. $^{43}$

\subsection{Social security contributions levied on pension income}

A fundamental shift in the perceived role of pension benefits occurred in the post-Word War II period, from providing a limited insurance function to old-age workers with incapacity to work, providing low benefits designated to supplement other income (part-time or lesser-paid labour), pension programmes were transformed into public savings schemes, particularly in countries with an earnings-related pension benefit design. The removal of the incapacity to work as an eligibility criteria and an increase in benefit levels introduced a completely new concept: individuals should not work after reaching a certain age, healthy or not, because through their lifetime contributions they have earned the right to a work-free period of retirement and, in most cases, a period free of contributions to social security systems (with the exception of contributions to health care systems in those countries in which public health systems are integrated in social security).

In Portugal, health care systems are not included in social security. As such, like in most OECD countries social security contributions are levied only on gross labour income, and used to finance pensions (old-age, survivors, disability), unemployment, sickness and death insurance, or family and maternity benefits. Before 2011, pension income (public and private) was exempt from social contributions. However, in 2011, the Portuguese government was under pressure to consolidate the budget and was forced to adopt reforms with significant shortterm effects, one of which was the introduction for the first time of an extraordinary (social) solidarity contribution, so-called CES, levied on public and private pensions above a certain amount.

Politically advocated and justified as being a temporary measure to broaden the social contributions tax base, part of a policy to spread the burden equally between different cohorts of citizens and generations (both active and retired), the argument found no general acceptance. The measure soon become one of the main issues in the national political debate, focusing on the question of whether there were legal boundaries to how much pension reforms could impact on the 'acquired rights' of pensioners, on whether CES took into account the principle of progressivity and proportionality in the PIT tax code, and on to what extent could CES, being a social surcharge to PIT rates, constitute a second tax on the same pension income. The Portuguese Constitutional Court has been requested to rule on the matter several times in the last four years, deciding sometimes in favour of government, in others the Court found the measures unconstitutional and overruled them and ordered to fully or partially reimburse the pensioners affected. In reality, CES was simply an alternative way to nominally reduce pension benefits, similar to that which would be obtained through direct cuts, temporary freezes and/or permanent reduction of the indexation of benefits. Despite serious

\footnotetext{
${ }^{43}$ There are tax exemptions for income from participation units in Funds of Funds established and operating under national legislation, and for Venture Capital Funds that are exempt from CIT when established and operating under national legislation. Real Estate Investment Funds in Forest Resources are also exempt from CIT when established and operating under national legislation, as long as: a) at least $75 \%$ of its assets are allocated to the exploitation of forest resources, and b) that exploitation is submitted to forest management plans or certification.
} 
Constitutional Court remarks, the contribution was reformulated many times during this period to increase the taxable base and/or the number of tax brackets (Table 3 ).

Table 3 | Evolution of Extraordinary Solidarity Contribution (CES) in Portugal

\begin{tabular}{|c|c|c|}
\hline Year & Monthly pension & CES \\
\hline 2011 & $>€ 5.000$ & $10 \%$ \\
\hline \multirow[t]{2}{*}{2012} & [12-18] IAS & $\begin{array}{l}25 \% \text { of the benefit payment between } 12 x I A S(5030,64 \text { EUR) and } \\
18 x \text { IAS ( } 7545,96 \text { EUR) }\end{array}$ \\
\hline & $>18$ IAS & $50 \%$ of the benefit payment above 18xIAS $(7545,96$ EUR) \\
\hline \multirow{5}{*}{$\begin{array}{l}2013- \\
2014\end{array}$} & {$[1350-1800] €$} & $3,5 \%$ of the monthly pension between $€ 1350$ and $€ 1800$ \\
\hline & {$[1800-3750] €$} & $\begin{array}{l}3,5 \% \text { of } € 1800+16 \% \text { of the amount exceeding } € 1800 \text { but below } \\
€ 3750\end{array}$ \\
\hline & [3750-12 IAS] $€$ & $10 \%$ of the monthly pension between $€ 3750$ and $€ 5030,64$ \\
\hline & [12 - 18] IAS & $25 \%$ of the benefit payment between $€ 5030,64$ and $€ 7545,96$ \\
\hline & $>18$ IAS & $50 \%$ of the benefit payment above $18 x$ IAS ( $€ 7545,96)$ \\
\hline \multirow{2}{*}{2015} & [11 - 17] IAS & $15 \%$ of the monthly pension between $€ 4611,42$ and $€ 7126,74$ \\
\hline & $>17$ IAS & $40 \%$ of the benefit payment above $17 x \mid A S(€ 7126,74)$ \\
\hline
\end{tabular}

Source: Author, based on national legislation. Note: IAS $=419,22$ EUR. The application of CES contribution in 2015 cannot result in a monthly pension of less than EUR 4611,42.

To have an idea of the fiscal burden on retirement income, a pensioner receiving a monthly benefit of at least 17 IAS (EUR 7126,74) in 2015 will pay a marginal tax rate of $91.5 \%{ }^{44}$ on the amount exceeding $€ 7126,74$. This means that for some groups of pensioners CES is actually imposing a ceiling on pension benefits. The majority of European Union countries do not charge any social security contributions on public and private pension benefits, and those who do it mostly refer to health, sickness or long-term care insurance coverage (OECD, 2015). For instance, in Australia, Austria, Belgium, Chile, Finland, Germany, Israel, Japan, Korea, the Netherlands and Poland only health-insurance related social contributions are levied on pension income. The current relevant exceptions are Portugal, France, Belgium, Norway; a former exception was Italy (Table 4).

In Portugal lump sum payments from occupational pension plans are exempt from CES. This means social contributions on pension income penalize annuitization decisions, i.e., undervalue longevity risk protection. Personal private pension funds and other saving schemes are also exempt from CES which means equity among retirement saving vehicles has not been guaranteed. The contribution was supposed to be temporary and part of the bailout program, but although the universe of taxpayers has been mitigated in 2015, it is still in force.

\footnotetext{
${ }^{44}$ Marginal IRS tax rate $(48 \%)+$ additional surcharge $(3.5 \%)+$ CES $(40 \%)=91.5 \%$.
} 
Table 4 | Social security contributions on pension income

\begin{tabular}{|c|c|}
\hline Country & Social security contributions on pension income \\
\hline Portugal & Special Solidarity Contribution between $15 \%$ and $40 \%$ of monthly benefits \\
\hline France & $\begin{array}{l}\text { General scheme for employees (RGAVTS) and Complementary schemes for } \\
\text { employees (ARRCO) and management staff (AGIRC): Generalised social contribution } \\
\text { (CSG) of } 6.6 \%, 3.8 \% \text { or exemption (according to taxation); contribution for the } \\
\text { repayment of the social debt (CRDS) of } 0.5 \% \text {; additional solidarity contribution for } \\
\text { independent living (CASA) of } 0.3 \% \text {; Complementary schemes for employees (ARRCO) } \\
\text { and management staff (AGIRC): Contribution of } 1.0 \% \text {. }\end{array}$ \\
\hline Belgium & $\begin{array}{l}\text { Solidarity contribution in the field of pensions varying from } 0.5 \% \text { to } 2 \% \text { according to } \\
\text { the family charge and the gross amount of all statutory and non-statutory pensions. } \\
\text { Minimum amount for pension is EUR } 2,569.12 \text { (couple) or EUR } 2,222.18 \text { (single) per } \\
\text { month. }\end{array}$ \\
\hline Italy & $\begin{array}{l}\text { Contributo di solidarietà for pension benefits above } 5 \text { minimum wages (Fornero } \\
\text { reform); Current rules establish contribution rates between } 6 \% \text { and } 18 \% \text { for } \\
\text { pensions above } 14 \text { minimum wages; Contributo di perequazione, } 2011 \text { (5\%-15\% for } \\
\text { annual benefits above } 90.000 €\end{array}$ \\
\hline Norway & $\begin{array}{l}\text { Pension income is subject to social security contributions at a lower rate than other } \\
\text { types of income }\end{array}$ \\
\hline
\end{tabular}

Source: OECD (2015) and MISSOC Comparative Tables Database with author's additions.

\subsection{A place in the sun and a tax-free pension: PIT regime for non-regular residents}

In 2009 Portugal implemented a PIT system for the non-regular resident with the purpose of attracting to Portugal non-resident professionals qualified for activities with high added value, intellectual or industrial propriety or knowhow ${ }^{45}$, as well as beneficiaries of pension schemes granted abroad, offering a more beneficial tax burden. The non-regular resident tax regime is available for citizens deemed resident on Portuguese territory for tax purposes in the year to be taxed as a non-regular resident, that have not been deemed resident on Portuguese territory during the prior five years. Once granted, the regime applies for ten years (nonextendable) provided that, in each year, the individual meets the criteria to qualify as a tax resident.

For pensioners, the main advantage of this regime is that it offers tax exemption on pension income provided that (i) income is taxed in the country of its source based on the double tax treaty rules, or (ii) cannot be considered as Portuguese source income under the Portuguese domestic rules. ${ }^{46}$ For rental income, investment income and capital gains the exemption applies if the income may be taxed in the country of its source based on (i) the double tax treaty rules, (ii) the OECD Model Convention if no treaty exists between Portugal and the country of source of the income, provided, in this later case, that under the Portuguese

\footnotetext{
${ }^{45}$ The list of activities considered of high added value according to the provisions of the Personal Income Tax Code (CIRS) includes architects, engineers and similar, visual artists, actors and musicians, auditors and tax consultants, doctors and dentists, professors, psychologists, liberal professionals, technicians and alike and investors, managers and directors.

${ }^{46}$ For Portuguese source employment and self employment income deriving from a "high-value-added" activity, a $20 \%$ special flat PIT rate, with an additional surcharge of 3.5\%, applies.
} 
domestic rules, such income is not considered as Portuguese source income. Given the widely implemented system of deferred income taxation of pension benefits in most OECD countries, this special regime offers Portugal a significant competitive advantage in the cross-border taxation of pension income, but raises problems of international tax equity and neutrality, particularly when retired emigrants were exempted from income tax on their old-age pension saving in their home country.

\section{Is there a Rationale for a Semi-Dual Income Tax in Pension Taxation?}

The taxation of pensions directly affects consumption, saving, work, leisure and asset allocation decisions and public finances. It therefore has direct implications in key areas such as capital accumulation, productivity, economic growth, capital markets and welfare. The adoption of a specific taxation regime should be aligned with the pension system key objectives (consumption smoothing, basic protection for the vulnerable elderly), recent reform trends (such as recognizing the urgency of addressing the effects of population aging and decline, increasing statutory retirement ages) and severe constraints in enabling environments (such as public finance imbalances or a prolonged low interest-rate scenario). The implications of a given taxation regime for income and wealth distribution and public revenue should not be neglected. Important issues such as tax neutrality and tax equity (horizontal and vertical), risk sharing between governments and households, opportunistic behaviour or the need to simplify the tax system and increase transparency should also be taken into consideration.

The DIT was introduced in the Nordic countries in the early $1990 \mathrm{~s}^{47}$ as a compromise between a SHS tax and an expenditure tax, the two opposite poles recognized by conventional tax theory for a personal tax based on the ability to pay principle. Under the DIT system, the taxpayer's total tax bill depends not only on his aggregate income, but also on the split of that income between capital income and other forms of income. This does not accord with the philosophy of SHS or FKM tax. ${ }^{48}$ The Nordic countries choose to walk away from progressive taxation of capital income as a means of redistributing income because they have concluded that progressive taxes on capital income are not good at achieving progressivity, and may even have unintended effects. Since then, Portugal and other EU countries (e.g., Austria, Belgium, Italy, and Lithuania) have gradually moved towards a semi-dual income tax system, where different nominal tax rates apply to capital and non-capital (including pension) income.

Against this background, the questions that naturally emerge are: (i) to what extent is SDIT a system that, compared to TTE or EET, better suited to address the personal and policy goals of a pension scheme and of the economy? (ii) Is there a theoretical or practical rationale for a SDIT in the taxation of occupational and private pensions and other retirement income? (iii) What are the arguments for and against DIT and SDIT in the context of pension taxation? ${ }^{49}$ (iv)

\footnotetext{
${ }^{47}$ The dual income tax was introduced in Sweden in 1991, Norway 1992, and Finland 1993. The idea originated in Denmark, and was implemented in their 1985 tax reform. Later they introduced a hybrid system, mostly due to redistributive concerns. Later Austria, Belgium, Iceland, Italy, Japan, and Portugal have introduced tax systems that have some similarities to a dual income tax, with separate tax schedules for labour income and interest income.

${ }^{48}$ Critics of the DIT system have also pointed out that the system requires a splitting of the income of active owners of small firms into a capital income component and a labour income component, involving non negligible administrative challenges. Furthermore, the system provides an incentive for tax avoidance through the transformation of labour income subject to high marginal tax rates into capital income subject to lower tax rates.

${ }^{49}$ For a detailed discussion on the merits and drawbacks of DIT see Sørensen $(1994,2005)$ and Boadway $(2004)$.
} 
Is there is a rationale for taxing capital income at a lower marginal rate(s) than other income? (v) Why should we combine a flat tax on capital income with a progressive rate schedule for labour and pension income?

In making this discussion, besides the normal pension scheme goals we will assume there are four main competing considerations an open economy faces in designing a pension taxation regime. At the domestic level, the first goal is tax progressivity. This goal addresses vertical equity concerns by requiring high-income individuals or families to pay a higher proportion of their income in tax. The second goal is comprehensiveness, which requires equal (and joint) treatment of all sources of income. This addresses horizontal equity concerns, and in conjunction with the first goal, results in taxing individuals in accordance with "ability to pay" principles. The third goal is symmetry, which exists when all types of capital income are subject to the same tax regime. This goal addresses concerns of allocative efficiency as well as taxinduced distortions in investment and savings decisions. Symmetry is important because large differences in tax rates are likely to distort economic choices and for preventing domestic tax avoidance. At the international level, the mail goal is competitiveness or international efficiency, but topics like the portability of pension entitlements and discriminating tax treatment in the Single Market can run counter to all the four freedoms laid down in the EC Treaty. This goal addresses international tax competition on capital (and, in some cases, labour and pension) income that forces governments to cut some tax rates on capital income down to "international standards" to maintain competitiveness. Discriminating tax treatment with respect to domestic and foreign recipients or providers of old-age pensions is a source of potential restrictions for free mobility of services, labour, and capital and may deter free mobility of workers.

In a closed economy and without life-time income considerations, a SHS tax can theoretically satisfy the progressivity, comprehensiveness and symmetry objectives. When international competitiveness is added to the three domestic tax policy goals, countries may not be able to fulfil all goals, particularly as cross-border mobility of capital varies both between types of capital and economic regions, and will have to sacrifice or compromise some of them. As the recent Portuguese experience shows, economic, political and social factors will ultimately determine which objective to sacrifice.

\subsection{Sacrificing comprehensiveness: The central role of savings taxation}

Countries that adopted DIT systems abandoned comprehensiveness, i.e., the joint treatment of capital and non-capital incomes in an attempt to maintain "symmetry" while at the same time responding to strong tax competitive pressures. By taxing all accruals to income, whether from earnings or investments, irrespective of whether they are saved or consumed, SHS tax discriminates in favour of current consumption, it is not neutral with regard to present and future consumption and acts as a disincentive to (particularly long term) saving. ${ }^{50}$ Savings, particularly contributions to pension schemes, is not a normal commodity, for most individuals is a way to finance deferred consumption. The taxation of savings has a central role in the tax

50 The tax treatment of savings is a critical determinant of the extent to which the tax system recognizes interpersonal differences in lifetime income, as opposed to consider annual income only. To equalize the tax burden on taxpayers with similar lifetime incomes but different income patterns over their life courses careful design of the tax treatment of savings is crucial. 
treatment of pensions. Pension taxation can affect both the total amount of savings in the economy and how those savings are allocated across different assets. This can directly affect the amount and efficiency with which capital is invested. Under a SHS tax, saving out of current income is double-taxed: once when the income is earned and again when the return on investment is earned. This means that when stated in life-cycle perspective, horizontal equity is violated under an SHS tax. Applying a lower capital income tax rate in SDIT is seen as a way to mitigate the bias against future consumption and to alleviate the impact of taxing nominal (and not real) rates of return. Whitehouse (1999) suggests that under the strict (and unrealistic $^{51}$ ) assumptions a consumption-type TEE and EET are equally optimal. They both confer a post-tax rate of return to saving equal to the pre-tax rate of return and are neutral between consumption now and consumption in retirement. However, there would be no general equivalence for a pension or tax policy change that would be unanticipated by households and where tax rates would differ over the lifecycle. The marginal tax rate during retirement is typically lower than during working life, making pension savings more attractive under the EET regime. EET system offers taxpayers an extra degree of freedom to smooth consumption over their life cycle. TEE systems shift the tax burden to working-aged agents and away from retirees, reducing the after-tax income that workers can allocate between consumption and savings.

The are additional arguments that help to justify a more favourable fiscal treatment of capital income and retirement saving in Portugal. Among them we highlight the desire to increase the number of people that save to finance their retirement or to increase the amount saved, increasing the supply of long term funds to capital markets that promote investment and economic growth ${ }^{52}$. Other issues such as bounded rationality and bounded willpower problems, the desire to reduce the currently high number and significance of those that are likely to fall into the safety net when in retirement, increasing the already too high fiscal pressure, or the illiquidity of pension rights are also relevant. Saving for retirement is particularly low in Portugal and will need to increase significantly in the future to address both sustainability and adequacy problems in PAYG systems. ${ }^{53}$ In a scenario in which individuals will be increasingly in charge of their own financial security after retirement, recent surveys show that Portuguese citizens are not well-equipped to make saving decisions, with many reporting not being able to plan for retirement. Financial literacy levels are low and misconceptions about the sustainability and generosity of public PAYG schemes have already weakened precautionary savings and savings motivated by life cycle considerations.

Another justification for favouring retirement savings concerns the effects of tax rates on the composition of savings, namely the positive effects that may be achieved by channelling savings through retirement saving vehicles. Retirement saving has the potential to contribute to the development of capital markets and economic growth by increasing the demand for long-term securities and by promoting the institutionalization of asset management. The

\footnotetext{
${ }^{51}$ It is assumed, for instance, that there are no regular contributions are paid during accumulation, only an initial one, and that marginal tax rates during work and retirement are identical.

52 Empirical evidence shows that the effects of tax incentives on national saving may be either positive or negative. If the evidence on taxing more favourably pensions suggests that it can contribute to higher private saving, the consequence for national saving depends on the response of governments and individuals (see, e.g., Feldstein, 1974; Kohl and O'Brien, 1998; Attanasio and Brugiavini, 2003; Pfau, 2005).

${ }^{53}$ Additionally, the country has the highest combined debt level in the Euro-zone at over $360 \%$ of GDP.
} 
distinctive characteristics of saving for retirement vehicles ${ }^{54}$ as opposed to those of other asset managers imply that the portfolio composition is likely to include a significant fraction of longterm debt, equities and real estate while that of liquid assets tends to be small. To the extent that a high demand for these types of assets has positive effects on investment, productive capital formation and growth $^{55}$, there may be a case for providing tax incentives for channelling savings into retirement vehicles. Even if saving and wealth did not increase, a more favourable fiscal treatment of retirement saving is expected to increase the supply of long term funds to capital markets, thus improving notably the performance of the function of transferring resources. ${ }^{56}$ This is particularly important in countries like Portugal in which capital markets have been struggling in recent years following the world financial crisis of 2008, the 2011-2014 bailout program, high risk premiums, increased competition at the EU level, excessive dependence on the banking channel, recent bank restructuring and failure episodes, lack of trust in financial institutions, comparatively low liquidity levels and no major recent IPO's.

Another justification for favouring retirement saving vehicles in Portugal has been the contribution of contractual savings institutions to the development of financial markets, namely by promoting the concentration of asset management in large institutions. ${ }^{57}$ Collective saving management has the potential to be superior to individual management because of the economies of scale in risk-pooling, in collecting and managing information, in terms of transaction costs, in promoting liquid market structure, in increasing the demand for capital market instruments, in promoting financial innovation, in improving corporate governance, in providing more and better quality information to shareholders. The fact that institutional investors exert a beneficial role in financial markets does not necessarily justify a special taxation regime. For the contrary, the link between effective tax rates and distortions to the pattern of saving has been clearly established, particularly in countries like Portugal in which retirement savings vehicles are sold primarily because of their favourable treatment by the tax system, with little attention given to the profitability of the underlying investments. This means distortionary effects in the structure of the financial services industry induced by taxation regimes must be balanced with the ability of the capital markets to channel savings into the most efficient investments and with distributional considerations since the value of tax incentives usually increases with taxpayers' marginal rates and retirement wealth tends to be concentrated in high income households.

Ensuring a consistent and comprehensive taxation of all forms of capital income is not trivial from the political and practical point of view. These difficulties imply considerable differences

\footnotetext{
${ }^{54}$ Inflows and outflows are comparatively more stable and predictable; asset allocation is set-up to maximize the return on investment in a long term perspective; liabilities are generally non-tradable, which means that there are lower lapse risks; lower transactions costs; comparatively lower costs charged for managing contributions and assets; regulatory constraints; comparative advantage in compensating for the increased risk by pooling and diversifying across assets whose returns are imperfectly correlated.

${ }^{55}$ By providing more risk-capital to firms, by reducing long-term interest rates, by diminishing the cost of equity and debt/equity ratios, by reducing the dependence on bank finance, by providing more stable financing.

${ }^{56}$ Besides the quantitative effects noted above, the development of retirement saving vehicles is also likely to trigger qualitative developments in financial markets (financial innovation, increased competition to the banking sector, modernisation of the infrastructure of securities markets) which will facilitate in particular the functions of managing uncertainty and controlling risk, and providing price information.

${ }^{57}$ Catalan et al. (2000) argue that among institutional investors, contractual savings institutions (pension funds and life insurance companies) are the most effective at developing capital markets.
} 
in the marginal effective tax rates on different types of saving and investment under SHS tax. A specific efficiency argument for proportional rather than progressive taxation of capital income is that the after-tax return to saving will differ across taxpayers when their marginal PIT rates are not identical. This means progressivity causes the marginal rate of substitution between present and future consumption to be different between taxpayers, implying intersectoral distortions of capital allocation and an inefficient allocation of the overall level of savings (Sørensen, 2005). Finally, the loss of vertical equity resulting from applying a proportional (and usually lower) rate on capital income (income from capital tends to be concentrated in the upper income brackets) may be largely offset by efficiency gains.

\subsection{Sacrificing symmetry: international capital mobility and other constraints}

The international capital mobility constraint. Portugal is a small significantly open economy with perfect international mobility of capital that critically depends on foreign saving to counterbalance its significant public and private indebtedness levels. If tax competitiveness is perceived as essential, and if according to the Portuguese constitution significant income tax progressivity is to be maintained, different types of capital income have to be taxed with widely differing rates. This option sacrifices symmetry objectives. In recent years global tax competition concerns in Portugal has prompted legislative proposals to reduce CIT rates significantly below tax rates under the PIT tax system. The option pursued in Portugal to differentiate tax rates on capital income has been largely determined by the elasticity of the tax base. Tax rates on the most sensitive types of capital income (e.g., dividends) are taxed under lower flat rates, while other are taxed under higher flat withholding tax rates or, optionally, kept within the ambit of progressive income taxation. Compared to immobile domestic factors like labour, capital has become increasingly mobile across international borders and, therefore, there is a significant risk that a high and progressive domestic capital income tax rate will induce taxpayers to costlessly escape domestic taxation by moving their wealth to foreign low-tax jurisdictions, despite recent years efforts made by the authorities to increase the monitoring and enforcement of taxes on income from capital invested abroad. In the absence of effective information exchange, even those countries that tax their residents on their world-wide income have limited capacity to tax their residents' foreign-source income effectively since the use of tax havens, off-shore accounts and bank secrecy laws make it difficult for taxing authorities to track the investments of their residents.

Recent banking failures and financial markets distress have also contributed to undermine the attractiveness of investing in Portugal. In this context, adopting SHS tax and increasing taxes on capital income would likely lead to a capital flight, an increase in the tax burden carried by the immobile domestic factors, and a reduction in investment, in capital intensity of production and potential growth. Portugal's adoption of a SDIT tax, the separation of the several flat capital income tax rates from the labour and pension income tax schedule allowed policy makers to levy comparatively lower capital tax rates, to reduce the risk of capital flight and to increase the attractiveness of FDI.

The problem of defining the capital income component. Some forms of capital income are simple to define in principle (e.g., interest income, dividends, royalties, and rents) and Portugal decided to tax them (by default) at a flat rate under a final withholding regime. The application 
of final common withholding taxes to these payments, whether to domestic or foreign recipients, is expected to improve efficiency by increasing the symmetry of tax treatment of capital income and simplify administration. Flat tax rates have increased significantly in recent years from $20 \%$ to $28 \%$. This is against both the goal of encouraging people to save more and the objective of allowing individuals to take personal responsibility for adequate income in retirement. The adoption of final withholding regimes has expanded the tax base and is likely to enhance the progressivity of the tax system.

Another question refers to how to tax net capital gains on corporate shares or real estate property at the individual level, an issue that was discussed for many years in Portugal and suffered many changes. In the past, the option was simply to exempt capital gains from taxation. There were competitiveness considerations behind this option, together with incentives for capital market development, and the argument that under a SDIT with full integration of distributed earnings and interest payments, any remaining gains on corporate shares largely reflect inflation. Then, for some years the option was to tax net capital gains only for shares held for less than a specific period of time (one year to be more precise). This approach deemed to create incentives to long-term (retirement) capital market investment, support privatization processes and to prevent taxpayers from engaging in schemes to avoid tax on labour income by selling their shares to reduce or evade tax liability. The current practice is to tax net capital gains at the individual level by a flat rate of $28 \%$. Since gains are taxed when realized, individual taxpayers are allowed to adjust the cost basis of their shares or property to reflect any taxed, but undistributed, earnings at the corporate level or depreciation and improvement costs. Taxing capital gains based on the realization principle may lead to asset retention and lock-in effects, which hampers the optimal allocation of resources. For capital gains realized from fixed assets such as real property, only $50 \%$ of the capital gains will be taxable if the capital gains are reinvested in fixed assets such as real property during the year the sale occurred, the previous year, or within two years after the sale. This has created an incentive for housing savings schemes during the accumulation phase of pensions, leveraged by the existence of housing tax deduction expenses, but challenges the decumulation phase due to the inexistence of equity release mechanisms in Portugal.

The fiscal revenue and unemployment constraints. The above discussion on the relative merits of SDIT in pension taxation has been implicitly based on the assumption that lower marginal tax rates on different forms of retirement capital income will require a higher marginal tax rate on labour income to comply with the government's fiscal constraint. However, in the current Portuguese context this assumption may be highly misleading given the already high marginal PIT rates, and excessive public debt and unemployment levels. Contrary to the pure form of the DIT, in which the PIT rate on capital income is aligned with both the CIT rate and the marginal tax rate on labour income in the first bracket, capital income tax rate in Portugal almost doubles that of labour income in the first bracket and is well above the CIT rate. This means the fiscal revenue constraint is likely to prevent further significant reductions in capital income tax rates. The adoption of separate tax rates for labour and capital income has both revenue and progressivity implications. In recent years the Portuguese response to both fiscal pressure and international tax competition has been to reduce $\mathrm{CIT}$ rates, increase flat withholding interest income taxes and significantly increase the 
current tax revenue generated from labour income, augmenting both the level and progressivity of the system.

Additionally, the Portuguese economy faced difficult challenges during the last decade, particularly during the "Troika" bailout period. In particular, substantial concerns exist about the current historically high levels of unemployment (from a 3.9\% unemployment rate at the beginning of the millennium, unemployment reached a maximum of $17.8 \%$ during 2013). These concerns helped to provide political support for reducing the tax burden on capital income, particularly rate cuts for CIT taxes, as a means to increase economic activity. The country faced critical choices in reforming its income tax system: increase tax rates for all income in order to generate sufficient tax revenue to support social programs and reduce the debt burden, undermining economic recovery efforts, or bifurcate the tax regime and apply lower rates to some forms of capital income while increasing the level and progressivity of labour and pension income taxes. Portugal chose the latter approach. The extent to whether a low flat rate tax on capital as contributed to increase investment and tax revenue is yet to be demonstrated since it is difficult to isolate the effect of tax changes on the costs of capital from the effect of other tax and fiscal reforms. The choice of a specific pension taxation regime has relevant current and intertemporal implications in terms of fiscal sustainability. While under a TEE system the government gives up the possibility of taxing part of citizens' future income, under an EET system it acquires a share in the retirement assets. ${ }^{58}$ The significant budgetary pressures in Portugal and the recent signs from the government in office that it will relax or abandon fiscal consolidation have triggered the discussion on a potential shift from TET to TEE in the taxation of occupational and private pension schemes and retirement savings, and on the creation of a wealth tax on real and financial wealth.

Reducing discrimination in favour of human-capital investment. The SHS tax tends to discriminate against financial and physical investment compared to investment in human capital by offering expenditure tax treatment of human capital investment. Because SHS tax taxes labour and pension income as they are earned, the cost of human capital investment (foregone wages and leisure, other cost items, etc.) implies an immediate deduction of a similar amount from taxable income. In this sense, while the costs of acquiring physical capital are only allowed to be capitalized and depreciated over the life of the asset, human capital investment benefits from "full expensing" under SHS tax. The progressivity of the labour income tax is then justified as a way to mitigate the private return to human capital investment, thereby offsetting the tendency of a proportional comprehensive income tax to discriminate in favour of such investments. The truth is that there are significant positive externalities from education and human capital is crucial for long term economic growth, which means the argument against «tax subsidies» on human capital investments implicit in SDIT regimes is weakened.

\footnotetext{
${ }^{58}$ This means, for instance, that under EET a government is exposed to increases in interest rates that raise the cost of public debt if the rate of return on pension assets does not follow. For the contrary, by shifting from EET to TEE (a proposal currently under discussion in the UK) a government can improve its current budgetary perspectives if does not relax its budgetary stance and the interest on public debt is higher than the return on pension assets. Even if the one-off revenues related to the shift from EET to TEE are not used by government to relax their fiscal stance, in an ageing society a shift from EET to TEE might increase revenues in a first stage and reduce them afterwards, when age-related expenditure will put more pressure on budgets.
} 


\subsection{Arbitrage Opportunities and the erosion of social contributions' taxable base}

The move from a SHS tax to a SDIT tax regime in Portugal offered significant tax planning (or tax evasion) opportunities by converting labour income from self-employment or from wages of owner-employees of closely-held corporations into income from capital. For medium and high income classes, there is a large difference in the marginal tax rates on capital and labour income, providing great incentives for income shifting. Starting in 2013, the combined reduction in the number of PIT tax brackets, the increase in PIT marginal rates and surcharges and the ongoing reduction in CIT rates to values now closer to the lowest marginal tax rate on labour income created a strong incentive to characterize income from labour as income from capital. Given that under the Portuguese (and many other countries) tax system labour income is subject to social security taxes, the move towards SDIT has substantially increased the effective marginal tax rates for labour income but left tax rates for capital income unchanged. As a consequence, the number of those registered self-employed dropped substantially in recent years while at the same time the number of new SME grew exponentially. For pension schemes, the immediate consequence has been a decline in both the taxable base for social contributions and contribution revenue.

To avoid such uneven tax treatment and to reduce the scope for tax avoidance, it would be necessary to align the CIT rate with the PIT rate on capital income, and equalize marginal capital income tax rates across taxpayers. In the short to medium run this objective is considered improbable given both international tax competitiveness considerations and the need to strengthen SME capital structure. Moreover, in Portugal a large percentage of corporate tax revenues come from a relatively small number of taxpayers, which means increasing CIT rates would likely contribute to reduce the tax base. This motivated the introduction of presumptive tax regimes that seek to tax micro and small businesses by reference to factors other than income, namely gross revenue. Alternatively, it would be necessary to split the income of the self-employed and the wages of owner-employees into a labour income component and a capital income component. ${ }^{59}$

\subsection{Equity, neutrality and risk-sharing considerations}

Tax equity has always been a critical point in tax policy design in Portugal. The question of how tax equity is perceived in the SDIT tax model is a key point in the debate and, as such, it should be approached from various angles. First, there is not a consensus on what is a socially acceptable indicator of a citizen's ability to pay, the basic principle of the income tax legislation in Portugal, and what should be after tax income distribution patterns. In an ideal world, policymakers would like to tax people according to their lifetime earning capacity. The problem is that we cannot observe the lifetime earning capacity directly and is difficult to measure inherited wealth, so governments tend to use actual earnings or expenditure as a proxy. Assuming that annual comprehensive income is a socially acceptable indicator of a citizen's ability to pay, SHS tax ensure horizontal equity (taxpayers with the same level of annual income are taxed equally) and, for a given consensus about the redistributive features of the system, properly graduated tax scales also guarantee vertical equity (taxpayers with higher incomes are taxed more heavily). However, when stated in life-cycle perspective, horizontal

\footnotetext{
${ }^{59}$ For an overview of alternative methods of income splitting see, for instance Sørensen (2005).
} 
equity is violated under a SHS tax since those who choose to consume later in life are taxed more heavily.

In Portugal and other countries very often it is argued that aggravating the taxation of (retirement) savings and capital income is an effective way to pursue redistribution goals since taxing capital income is a sort of presumptive way of taxing inheritances and gifts. The truth is that individuals with large savings are not wealthy by definition and not necessarily better off over their lifetime when compared to someone without savings. They might simply earn and spend similar amounts over their lifetimes, but at different moments. By taxing the interest income from savings, we are not taxing the wealthier individuals; we are taxing those who spend their money tomorrow rather than today, and due to the compound interest effect, we are taxing more the longer the investment horizon involved, something that is particularly harmful in the taxation of pensions. ${ }^{60}$

Neutrality over the timing of consumption should only be a reasonable starting point for tax design of pensions and retirement income. The taxation of savings affects individuals decisions on how much to save, when to save, how to allocate savings across different assets and how much risk to take when allocating their savings between assets. It therefore directly affects their welfare. In principle, tax policy shouldn't determine the savings vehicles or assets (pensions, real estate, insurance, other financial assets) in which individuals invest their savings. In reality, there are strong reasons for deviating from this form of neutrality when it comes to treat pensions more generously than other forms of savings in SDIT since this creates an incentive to save for retirement income to individuals who are short-sighted and otherwise may not worry and plan for their long term financial needs. Neutrality at the international level or between alternative payout options at retirement should also be taken into consideration.

In standard SHS tax, capital gains and other forms of income from savings are taxed at the same moment in time. To make it applicable, this implies taxing assets on accrual (when capital appreciation occurs) rather than on realization (on disposal of the asset), a requirement that although possible it may be difficult to implement. ${ }^{61}$ For an asset that is held for a long period of time before being sold and appreciates, the effect of taxation on realization is to defer the tax payment on the accrued capital gain, something that has been highly valued by Portuguese taxpayers. In an inflationary context in which nominal interest rates accommodate to maintain the real return on investment, taxing nominal returns increases the effective tax rate on real return to interest-bearing assets. This means SHS taxation of savings is unable to guarantee neutrality over time and providing for some tax relief on capital income is justified under a DIT or SDIT tax.

The appropriate treatment of retirement savings and pension income should not neglect the impact of a given taxation regime on portfolio composition and risk taking. Tax effects on portfolio composition may be of many types, not all of which may be expected to have any

\footnotetext{
${ }^{60}$ This is an option that is both unfair and inefficient The only exception would be if people's saving decisions tell us something more about their underlying resources and earning capacity than just about their preferences for current versus future consumption. The main way to redistribute is to make the tax rate scale applied to earnings (money at its source) or expenditure (money when it is finally used for consumption) more progressive.

${ }^{61}$ For instance, all assets would need to be 'marked-to-market' or valued in periods when they are not traded. In PAYG systems, the internal rate of return would need to be estimated.
} 
systematic bias in favour of retirement assets. The traditional argument for a systematic effect of taxation on portfolio choice runs in terms of risk-taking behaviour, namely that the taxation of returns from assets discriminates against risk taking through its lowering of the expected rates of return. The truth is that, for instance, in EET regimes in addition to taking a share in the expected return the government also shares in the risk, it becomes co-investor. The risk exposure is total if there are perfect loss offset provisions, in which case the government will in fact carry the same share of a possible loss as it takes in a gain, or partial if there is no loss offset. A tax deferral regime has better (intra and intergenerational) risk sharing properties than a prepaid expenditure tax model. ${ }^{62}$ By exploiting the benefits of intergenerational risksharing, more risk can be taken, which results in higher expected returns.

Moving now to the payout phase, there are important welfare effects that can justify sharing longevity risk between annuitants and annuity providers and the adoption of a tax deferral regime. First, longevity risk involves very long time horizons. For instance, for an individual buying an annuity at age 50 and living to 100, there are 50 years of mortality uncertainty involved in the contract. Second, longevity risk has aggregate components (e.g., medical breakthroughs may change aggregate longevity) that cannot be diversified and are best managed when shared over a larger pool. Finally, the net exposure to longevity risk varies across cohorts, which differ in their ability to respond or self-insure.

\section{Conclusions}

Semi-dual income tax systems combine a highly progressive tax schedule for labour and pension income with low and flat nominal tax rates on some forms of capital (personal and corporate) income. This paper discussed the rationale for the adoption of SDIT in the taxation of public, occupational and private pensions and other retirement income, taking the Portuguese experience as a case study. Moving to a SDIT offers both advantages and disadvantages in addressing the pension system long term goals and challenges, and represents a compromise between the many domestic and international competing considerations an open economy faces in designing a tax regime and the constraint to achieve a given tax revenue.

The adoption of a SDIT in pension taxation involves sacrificing some tax comprehensiveness, i.e., the joint treatment of capital and non-capital incomes in an attempt to maintain some "symmetry" while at the same time responding to strong tax competitive pressures. Contrary to SHS tax that discriminates in favour of current consumption, taxes twice income saved and acts as a disincentive to (particularly long term) saving, applying a lower capital income tax rate in SDIT is seen as a way to mitigate the bias against future consumption and to alleviate

\footnotetext{
62 Romaniuk (2013) argues that this near equivalence between EET and TEE regimes in taxing retirement savings breaks down when considering the tax effects on risk-taking. In particular, the author concludes that the TEE regime is risk-taking neutral, while the EET regime does not, in general, respect this property. Chen et al. (2014) explore the benefits of intergenerational risk-sharing through both private funded pensions and via the public debt considering two possible instruments to stabilise pension funding ratios, namely the pension contribution and the indexation of pension rights, and two possible tax regimes, EET and TEE. The authors conclude that under EET participants in a pension scheme are effectively able to save a larger proportion of income for their retirement than under TEE and, therefore, benefit more from the positive expected equity premium but are also exposed to more volatile consumption paths due to tax policy aimed at stabilising public debt. From a welfare perspective, EET also outperforms TEE.
} 
the impact of taxing nominal (and not real) rates of return. Other arguments which could justify a more favourable fiscal treatment of capital income and retirement saving include the desire to increase the number of people that save to finance their retirement and/or the amount saved, addressing both sustainability and adequacy problems in PAYG systems, significant bounded rationality and bounded willpower problems demanding special tax incentives, or the desire to reduce the number and significance of those that are likely to fall into the safety net when in retirement. Another justification for favouring retirement savings concerns the effects of tax rates on the composition of savings, namely the positive effects that may be achieved by channelling savings through retirement saving vehicles in boosting capital markets, contractual savings institutions, investment, productive capital formation and economic growth.

The adoption of a SDIT in pension taxation involves sacrificing some tax symmetry, i.e., applying different tax rates to some types of capital income, in an attempt to respond to international tax competitiveness and the need to attract FDI to counterbalance public and private indebtedness levels, while at the same time maintaining significant income tax progressivity to cope with redistributive goals and constitutional constraints. The decision on which capital income sources will benefit from differentiated tax rates tends to be largely determined by the elasticity of the tax base, with the most sensitive types of capital income taxed at lower flat rates, while others are taxed under higher flat withholding tax rates or, alternatively, kept within the ambit of progressive income taxation. This decision can also be influenced by problems in defining the capital income component, the desire to create incentives to long-term capital market investment or the need to support privatization processes. Contrary to the pure form of the DIT, in which the PIT rate on capital income is aligned with both the CIT rate and the marginal tax rate on labour income in the first bracket, the Portuguese experience shows that capital income tax rates in SDIT are largely determined by fiscal revenue constraints, international tax competition pressure, unemployment and tax wedge considerations and inequality and progressivity concerns.

The move to a SDIT tax regime offers significant tax planning (or tax evasion) opportunities by converting labour income from self-employment or from wages of owner-employees of closely-held corporations into income from capital, eroding the social contributions' taxable base and offering non negligible tax arbitrage opportunities. The elimination of these tax arbitrage opportunities may be difficult if aligning the CIT rate with the PIT rate on capital income and equalizing marginal capital income tax rates across taxpayers conflicts with both international tax competitiveness considerations and the need to strengthen SME capital structure.

The move to a SDIT in pension taxation also raises equity, neutrality and risk-sharing considerations. It is well known that in a life-cycle perspective, horizontal equity is violated under an SHS tax since those who choose to consume later in life are taxed more heavily. This means SDIT tax can be justified as a means of achieving neutrality over the timing of consumption. Additionally, SHS taxation of savings is unable to guarantee neutrality over time. This provides for some tax relief on capital income under a SDIT tax and for tax deferral regimes that exhibit better (intra and intergenerational) risk sharing properties when compared to a prepaid expenditure tax model. The adoption of a SDIT in pensions taxation 
affects individuals decisions on how much to save, when to save, how to allocate savings across different assets and how much risk to take when allocating their savings between assets. This departure from neutrality is justified by the need to encourage saving for retirement between individuals who are short-sighted and otherwise may not worry and plan for their long term financial needs.

Global competition provides strong incentives for countries to reduce tax rates and to create special regimes for non-regular residents. Providing separate tax rates for labour and capital income allows countries greater flexibility in addressing international tax competition and greater opportunity to retain and augment progressive tax rates for labour and pension income. Conversely, tax induced distortions (over the level and timing of saving and between different types of savings vehicles or assets) and arbitrage opportunities for income-shifting between categories should not be neglected. The recent changes in Portugal were not the result of a clear tax reform strategy but an outcome of economic, demographic, political and social circumstances. Although countries face much different economic, political, social and tax environments from those of Portugal or the Nordic countries, the semi-dual income tax may be an appropriate solution to the many challenges involved in the taxation of pensions. 


\section{References}

Attanasio, O. P., and A. Brugiavini (2003). Social Security and Households' Saving. Quarterly Journal of Economics 118, 3: 1075-1119.

Boadway, R. (2004). The Dual Income Tax System: An Overview. CESifo Dice Report 2 (3), 3-8.

Bravo, J. M., Afonso, L. e Guerreiro, G. (2013). Avaliação Actuarial do Regime de Pensões da Caixa Geral de Aposentações: formulação actual e impacto das medidas legislativas, Relatório integrante do dossier enviado ao Tribunal Constitucional no âmbito da apreciação da constitucionalidade do diploma sobre a convergência dos regimes de pensões (Proposta de Lei n.. 171/XII de 13 de Setembro de 2013).

Bravo, J. M., Afonso, L. e Guerreiro, G. (2014). Avaliação Actuarial do Sistema Previdencial da Segurança Social e Prestação Única da Segurança Social. Gabinete de Estratégia e Planeamento, Ministério da Solidariedade, Emprego e Segurança Social, Lisboa, Dezembro.

Bravo, J. M. (2016). Taxation of Pensions in Portugal: A Semi-Dual Income Tax System. CESifo DICE Report - Journal for Institutional Comparisons. 14 (1), 14-23.

Catalan, M., G. Impavido and Musalem, A. (2000). Contractual savings or stock market development: which leads?. Social Protection Discussion Paper Series 20, The World Bank.

Chen, D., Beetsma, R., Ponds, E. and Romp, W. (2014). Intergenerational Risk-Sharing through Funded Pensions and Public Debt. CESIFO Working Paper № 4624.

Feldstein, M. (1974). Social Security, Induced Retirement, and Aggregate Capital Accumulation. Journal of Political Economy 82, 5: 905-26.

Kohl, R. and P. O'Brien (1998). The Macroeconomics of Ageing, Pensions and Savings: A Survey. OECD Economics Department Working Papers, No. 200, OECD Publishing.

OECD (2006). Fundamental Reform of Personal Income Tax. OECD Tax Policy Studies, No. 13.

OECD (2011). "Tax Treatment of Pensions and Pensioners", in Pensions at a Glance 2011: Retirement-income Systems in OECD and G20 Countries, OECD Publishing.

OECD (2015). Stocktaking of the Tax Treatment of Funded Private Pension Plans in OECD and EU Countries. OECD.

Pfau, W. (2005). The Effects of Social Security on Private Savings: A Reappraisal of the Time Series Evidence. MPRA Paper No. 19032.

Romaniuk, K. (2013). Pension fund taxation and risk-taking: should we switch from the EET to the TEE regime? Annals of Finance, 9(4), 573-88.

Sørensen, P.B. (1994). From the global income tax to the dual income tax: recent tax reforms in the Nordic countries. International Tax and Public Finance, vol. 1, pp. 57-79.

Sørensen, P.B. (2005). Dual income taxation: why and how? Public Finance Analysis, Volume 61, Number 4, 559-586.

Wellisch, D., Lorz, S. Thiele, K., and Gahl, R. (2008). Besteuerung der Altersvorsorge. Nomos, Baden-Baden.

Whitehouse, E.R. (1999). The Tax treatment of funded pensions. MPRA Paper, 14173.

Yoo, K.-Y., de Serres, A. (2005). Tax treatment of private pension savings in OECD countries. OECD Economic Studies No. 39, 73-110. 